\title{
Foliar Urea with N-(n-butyl) Thiophosphoric Triamide for Sustainable Yield and Quality of Pineapple in a Controlled Environment
}

\author{
Mohammad Amdadul Haque 1,2 ${ }^{\mathbb{D}}$, Siti Zaharah Sakimin 1,3,*iD, Phebe Ding ${ }^{1}$, Noraini Md. Jaafar ${ }^{4}$, \\ Mohd Khanif Yusop ${ }^{4}$ and Babul Chandra Sarker ${ }^{2}$
}

check for updates

Citation: Haque, M.A.; Zaharah, S.S.; Ding, P.; Jaafar, N.M.; Yusop, M.K.;

Sarker, B.C. Foliar Urea with

N-(n-butyl) Thiophosphoric Triamide for Sustainable Yield and Quality of Pineapple in a Controlled Environment. Sustainability 2021, 13, 6880. https://doi.org/

$10.3390 /$ su13126880

Academic Editor: Rolf D. Vogt

Received: 21 May 2021

Accepted: 8 June 2021

Published: 18 June 2021

Publisher's Note: MDPI stays neutral with regard to jurisdictional claims in published maps and institutional affiliations.

Copyright: (c) 2021 by the authors. Licensee MDPI, Basel, Switzerland. This article is an open access article distributed under the terms and conditions of the Creative Commons Attribution (CC BY) license (https:/ / creativecommons.org/licenses/by/ $4.0 /)$.
1 Department of Crop Science, Faculty of Agriculture, Universiti Putra Malaysia, Serdang 43400, Selangor, Malaysia; amdad80@gmail.com (M.A.H.); phebe@upm.edu.my (P.D.)

2 Horticulture Research Centre, Bangladesh Agricultural Research Institute, Gazipur 1701, Bangladesh; bsarker_64@yahoo.com

3 Institute of Tropical Agriculture \& Food Security (ITAFoS), Universiti Putra Malaysia, Serdang 43400, Selangor, Malaysia

4 Department of Land Management, Faculty of Agriculture, Universiti Putra Malaysia, Serdang 43400, Selangor, Malaysia; j_noraini@upm.edu.my (N.M.J.); ymkhanif@gmail.com (M.K.Y.)

* Correspondence: szaharah@upm.edu.my; Tel.: +60-127847290

\begin{abstract}
In agricultural production, nitrogen loss leads to economic loss and is a high environmental risk affecting plant growth, yield, and quality. Use of the $\mathrm{N}$ fertilizer with a urease inhibitor is thus necessary to minimize $\mathrm{N}$ losses and increase the efficiency of $\mathrm{N}$. This study aimed to evaluate the effects of N-(n-butyl) Thiophosphoric Triamide (NBPT) on the growth, yield, and quality of pineapple. The experiment involved two foliar fertilizer treatments: $1 \%(w / v)$ urea solution with NBPT $\left(2.25 \mathrm{~mL} \mathrm{~kg}^{-1}\right.$ urea) was treated as NLU (NBPT Liquid Urea), and the same concentration of urea without NBPT served as the control. Both were applied 12 times, starting 1 month after planting (MAP) and continuing once a month for 12 months. The application of urea with NBPT notably increased the above-ground dry biomass per plant ( $20 \%$ and $10 \%$ at 8 and $12 \mathrm{MAP}$, respectively), leaf area per plant $(23 \%$ and $15 \%$ at 8 and $12 \mathrm{MAP}$, respectively), N accumulation per plant (10\%), $\mathrm{PFP}_{\mathrm{N}}$ (Partial Factor Productivity) (13\%), and average fruit weight (15\%) compared to the treatment with urea alone (control). The analysis of quality parameters indicated that urea with NBPT improves TSS (Total Soluble Solids) (19\%), ascorbic acid $(10 \%)$, and sucrose $(14 \%)$ but reduces the total organic acid content $(21 \%)$ in pineapple. When using urea with a urease inhibitor (NBPT), there was a significant improvement in growth, yield, quality, and nitrogen use efficiency, with the additional benefit of reduced nitrogen losses, in combination with easy handling. Hence, urea with a urease inhibitor can be used as a viable alternative for increasing pineapple yield by boosting growth with better fruit quality.
\end{abstract}

Keywords: pineapple; N-(n-butyl) thiophosphoric triamide; growth; yield; quality; nitrogen use efficiency

\section{Introduction}

Pineapple is one of the major fruit crops in the tropics and sub-tropics, with enormous production, and is widely appreciated by customers globally for its taste and aroma [1]. It plays an important role in improving the human diet and is a source of fiber and micronutrients, especially vitamins and minerals [2]. In 2018, the world pineapple production was 29,929.843 thousand tons, in an area of 1193.318 thousand hectares, whereas the total production in Malaysia was 329.365 thousand tons, in an area of 10.556 thousand hectares [3]. Nitrogen is a fundamental nutrient for agriculture and global food security [4]. It is essential for the growth and development of plants and is a limiting factor for crop production [5]. For pineapple production, its demand is high, and it greatly affects the growth, yield, and quality of pineapple [6]. More than $110 \mathrm{tg}$ of $\mathrm{N}$ fertilizer is used annually to meet the growing demand for food for the world's human population [7]. However, only 
$30 \%$ to $50 \%$ of the applied nitrogen fertilizer is used by crops, the remainder being released into the environment as a greenhouse gas or washed into the water system, decreasing the efficiency of the applied nitrogen [8]. The principal explanation for this decrease is $\mathrm{N}$ losses from the plant-soil system in the form of ammoniotic volatilization, leaching, erosion, surface run-off, and denitrification [9]. These losses not only cause an economic problem for the farmer but also create environmental problems [10]. Urea is the most widely used $\mathrm{N}$ fertilizer globally as its favorable features of manufacturing, $\mathrm{N}$ content, cost, handling, storage, and transportation make urea a competitive N source [4]. Immediately after the application of urea, rapid hydrolysis takes place in the presence of water. This transforms urea into ammonium through urease activity, increasing the $\mathrm{pH}$ to a value favorable for the loss of ammonia. Improved $\mathrm{N}$ fertilizer management is therefore a solution for improving the performance of $\mathrm{N}$ usage and reducing $\mathrm{N}$ losses [11]. Increasing the efficiency of $\mathrm{N}$ fertilizer use by crops has been of great concern for decades [12]. Therefore, alternative application strategies that boost fertilizer effectiveness and reduce $\mathrm{N}$ losses need to be urgently established.

The inhibition of the urease activity that decreases hydrolysis is an approach to minimizing ammonia loss. Among several urease inhibitors being used in agriculture, NBPT is the most effective inhibitor so far. It can be used as a granular coating or urea melt and successfully inhibits urease activity, thereby slowing urea hydrolysis [13]. Upon application with urea, NBPT transforms into NBPTO (an analogue of NBPT), which is the real inhibitor of urease activity. The NBPTO bond lengths and angles are the same as those of urea, allowing the compounds to occupy the active position and thus limiting the activity of urease [14]. However, NBPTO is not directly added to urea, because it is less stable and deteriorates more rapidly than NBPT [12]. The potential benefits of urea with NBPT compared with commercial urea have been discovered by researchers $[15,16]$. Currently, NBPT is commercially available as an agrotain ${ }^{\circledR}$ that can reduce urease activity and loss of $\mathrm{N}$, increase the efficiency of nitrogen usage, and increase crop yield [15,17-19].

NBPT increased dry matter when used with urea in grazed pasture in New Zealand [20-22]. Dawar et al. [17] evaluated the effect of an urease inhibitor on ryegrass, where NBPT significantly increased the $\mathrm{N}$ response by $66 \%$ compared to the use of urea alone. Mathialagan et al. [23] showed that NBPT can increase shoot dry matter, N uptake, and NUE in wheat [24]. Kawakami et al. [25] observed an increase in plant height by $9.22 \%$ in cotton after urea and NBPT treatment. Zuki et al. [13] also observed higher chlorophyll, dry biomass, leaf area, yield, nitrogen uptake, and NUE in maize after NBPT-coated urea treatment than after urea treatment. Espindula et al. [26] recorded significantly higher wheat yield when urea was applied with a urease inhibitor. Khan et al. [27] observed 37.5\% wheat grain yield and $38 \%$ total $\mathrm{N}$ uptake increase with inhibitor-treated urea compared to plain urea. Rekowski et al. [28] found that urea with NBPT increased protein content by $3.36 \%$ and the baking quality of wheat compared to only urea treatment. Li et al. [29] reported that NBPT increases the apparent $\mathrm{N}$ recovery efficiency, but they did not find any significant difference in terms of yield. Superior sugar beet quality in terms of sugar yield and percentage of sucrose was recorded after treatment with urea and a urease inhibitor compared with the use of urea and other nitrogen sources [30].

Several researchers have focused on the growth, yield, and quality of pineapple in different ways. Sakimin et al. [31] performed field research on the growth and physiology of MD2 pineapple with different types of $\mathrm{N}$ fertilizer. Sossa et al. [2] experimented with pineapple residue with different ratios of nitrogen and potassium to see their effect on pineapple quality in Southern Benin. Omotoso and Akinrinde [32] evaluated the effect of different doses of nitrogen fertilizer on the growth, yield, and quality of pineapple in Nigeria. Similarly, Tewodros et al. [33] investigated the effect of inorganic N and P fertilizer on fruit yield and yield components of pineapple in Ethiopia. In recent years, the improvement in the yield and quality of crops for food and nutritional security has become of vital concern globally. Nitrogen use efficiency and the minimization of $\mathrm{N}$ losses to the environment are the ongoing economic and environmental concerns related to 
nutrient management for crop production. Previous studies have focused on improving yield and quality only through the soil application of nitrogen fertilizer from different sources at different rates, without any strategic research to reduce the loss of nitrogen by increasing the efficiency of the applied fertilizer. Currently, there is lack of information on the effectiveness of foliar urea with NBPT on the growth, yield, and quality of pineapple. Increased crop production without increasing $\mathrm{N}$ fertilizer use is an urgent challenge in agriculture. However, the use of NBPT with foliar urea can be a viable and effective technique to promote different responses in terms of the growth, yield, quality, and NUE of pineapple; reducing nitrogen use; and protecting the soil from the deleterious effects of chemical fertilizers. This technique will help to increase the yield of fruit, enhance nutritional security, and strengthen the national economy without increasing the amount of $\mathrm{N}$ fertilizer in sustainable manner. Improving the growth, yield, and quality of pineapple by increasing the nitrogen use efficiency by foliar application of urea with NBPT is a new avenue of research. Hence, this study was performed to evaluate the growth, yield, quality, and NUE of MD2 pineapple subjected to foliar fertilization with urea or urea with NBPT.

\section{Materials and Methods}

\subsection{Geographical Position, Climate, and Soil Condition}

The experiment was performed between March 2019 and August 2020 at the greenhouse of Farm 15, Universiti Putra Malaysia, Serdang, Selangor, Malaysia, which is located at latitude of $2^{\circ} 59^{\prime} 01.3^{\prime \prime} \mathrm{N}$ and a longitude of $101^{\circ} 43^{\prime} 57.0^{\prime \prime} \mathrm{E}$ (Figure 1). A data logger (Metcal Technologies) recorded the average maximum (daytime) and minimum (nighttime) temperatures as $38.6^{\circ} \mathrm{C}$ and $26.4^{\circ} \mathrm{C}$, respectively (Digital $\mathrm{CO}_{2}$ monitor $\mathrm{CO}_{2} \mathrm{~m}$ TL 2000, China).

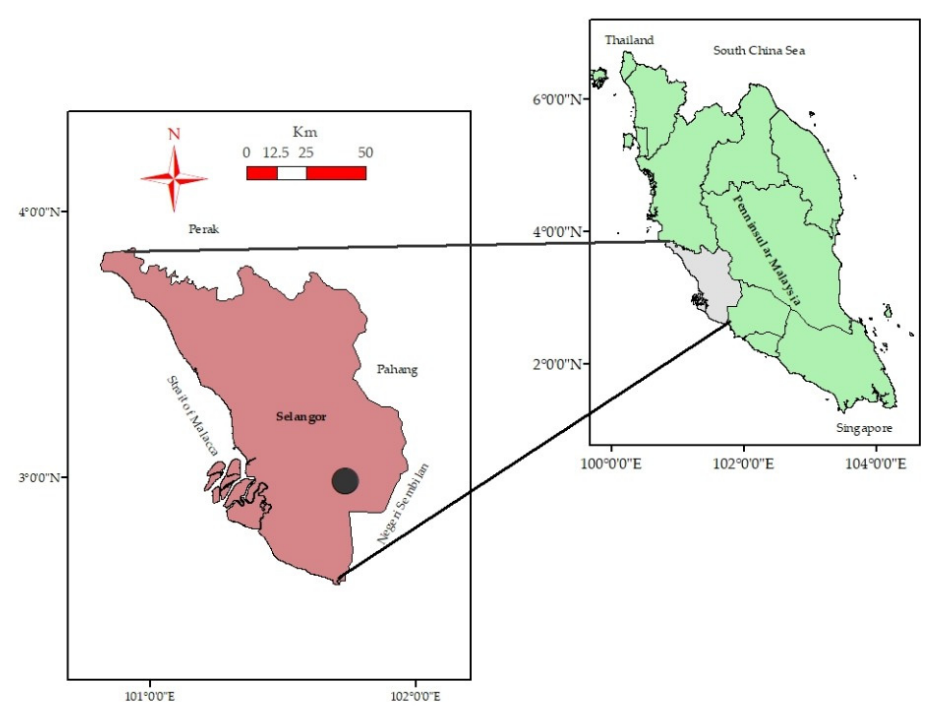

Figure 1. Location of the study area (black circled) in map.

The surface soil was collected from Farm 15, Universiti Putra Malaysia. The physicochemical properties of the soil are shown in Table 1. The $\mathrm{pH}$ of the soil, with a soil: distilled water ratio of 1:2.5, was determined by a $\mathrm{pH}$ meter from Mettler Toledo. The total $\mathrm{C}$ and $\mathrm{N}$ were analyzed using the Dumas combustion method with a carbon, hydrogen, nitrogen, and magnesium Laboratory Equipment Corporation (CHNS LECO) analyzer [34]; the available phosphorus was analyzed using the Bray No. 2 methods [35]; the available potassium, calcium, magnesium, and the cation-exchange capacity (CEC) were measured

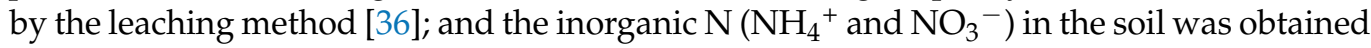
by distillation and titration according to Keeney and Nelson [37]. 
Table 1. Soil physical and chemical characteristics.

\begin{tabular}{cc}
\hline Parameter & Value \\
\hline Textural class & Sandy clay loam \\
pH & 4.59 \\
Organic C (\%) & 0.72 \\
Organic matter $(\%)$ & 1.24 \\
Total N $(\%)$ & 0.013 \\
Available phosphorus $\left(\mathrm{mg} \mathrm{kg}^{-1}\right)$ & 3.65 \\
Available potassium $\left(\mathrm{mg} \mathrm{kg}^{-1}\right)$ & 1.82 \\
Available calcium $\left(\mathrm{mg} \mathrm{kg}^{-1}\right)$ & 22.06 \\
Available magnesium $\left(\mathrm{mg} \mathrm{kg}^{-1}\right)$ & 5.58 \\
Cation-exchange capacity $\left(\mathrm{cmol} \mathrm{kg}^{-1}\right)$ & 5.51 \\
$\mathrm{NH}_{4}^{+}\left(\mathrm{mg} \mathrm{kg}^{-1}\right)$ & 2.67 \\
$\mathrm{NO}_{3}^{-}\left(\mathrm{mg} \mathrm{kg}^{-1}\right)$ & 1.25 \\
\hline
\end{tabular}

\subsection{Plant Growth Conditions and Experimental Setup}

Pineapple (Ananas comosus L.) suckers of the MD2 variety were collected from the Malaysian Pineapple Industry Board (MPIB) and planted in a $16 \mathrm{~cm} \times 16 \mathrm{~cm}$ polybag filled with $15 \mathrm{~kg}$ of soil. Thirty days before planting, the polybag soil was mixed with $20 \mathrm{~g}$ of a green fertilizer with $\mathrm{N}: \mathrm{P}: \mathrm{K}$ in the ratio of 15:15:15 and properly moistened with water. Before planting, the suckers were treated with malathion $(1.5 \mathrm{~mL})$ and benomyl $\left(1.0 \mathrm{~g} \mathrm{~L}^{-1}\right.$ of water). The suckers were planted in a 10-cm-deep hole in the soil in the polybag. A distance of $60 \mathrm{~cm}$ was maintained between the rows and $30 \mathrm{~cm}$ between the plants in each row. The plants were irrigated at 2-day intervals with a watering can to ensure moisture at the active root zones of the plants. The experiment involved two treatments: $1 \%(w / v)$ urea solution without NBPT, which served as the control, and the same concentration of

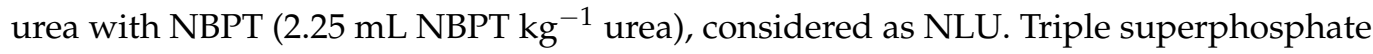
and muriate of potash were also added to both solutions at $1 \%$ and $0.7 \%$, respectively. Both sides of the leaf were given foliar treatment at $50 \mathrm{~mL}$ per plant every month, starting 1 MAP and continuing each month for 12 months, during the late afternoon, to facilitate nutrient absorption, as these plants belong to the CAM family. At 6 weeks after planting (WAP), $640 \mathrm{~g}$ of hydrated lime, $42 \mathrm{~g}$ of copper sulfate, $42 \mathrm{~g}$ of zinc sulfate, and $21 \mathrm{~g}$ of ferrous sulfate were dissolved in $18 \mathrm{~L}$ of water and sprayed at $100 \mathrm{~mL}$ per plant. The same amount of fertilizer with $640 \mathrm{~g}$ of urea was also dissolved in $18 \mathrm{~L}$ of water and applied at the same rate at $18 \mathrm{WAP}$. At $12 \mathrm{MAP}$, each plant was provided with $20 \mathrm{~g}$ of a granular fertilizer with $\mathrm{N}: \mathrm{P}: \mathrm{K}$ in the ratio of 12:12:17:2 TE in the soil and $50 \mathrm{~mL}$ of a flower induction hormone ( $30 \mathrm{~mL}$ of ethrel and $180 \mathrm{~g}$ of urea in $18 \mathrm{~L}$ of water) at the whorl of the leaf. The indicator leaf, identified as D leaf, was selected for all types of data. Dos Santos [38] confirmed that the $\mathrm{D}$ leaf should be used as an indicator for various analyses and any decision making.

\subsection{Observations}

\subsubsection{Determination of Plant Growth Traits}

Plant height $(\mathrm{cm})$, D leaf length $(\mathrm{cm})$, and D leaf width $(\mathrm{cm})$ were measured with a stainless steel ruler, the leaf number was manually counted, and the fresh and dry biomass of the above-ground and below-ground parts were recorded by a digital balance at 4,8 , and 12 MAP. The leaf area ( $\mathrm{cm}^{2} /$ plant) was measured by a leaf area meter (Model LI-3100).

\subsubsection{Chlorophyll}

Chlorophyll ${ }_{a}$, chlorophyll $l_{b}$, and chlorophyll ${ }_{(a+b)}$ were determined according to Aiman et al. [39]. Four discs of pineapple leaf were collected from the D leaf using a cork borer. The samples were immersed in an aluminum-foil-wrapped vial containing $20 \mathrm{~mL}$ of $80 \%(v / v)$ acetone and kept in the dark for 7 days to extract chlorophyll. $\mathrm{Chl}_{a}, \mathrm{Chl}_{\mathrm{b}}$, and $\mathrm{Chl}_{(\mathrm{a}+\mathrm{b})}$ were determined from the absorbance reading of a spectrophotometer (UV3101, PC, Shimadzu, Japan) at 664 and $647 \mathrm{~nm}$ wavelengths using the following formulae: 


$$
\begin{gathered}
\mathrm{Chl}_{\mathrm{a}}=13.19\left(\mathrm{~A}_{664}\right)-2.57\left(\mathrm{~A}_{647}\right) \\
\mathrm{Chl}_{\mathrm{b}}=22.1\left(\mathrm{~A}_{664}\right)-5.26\left(\mathrm{~A}_{647}\right) \\
\mathrm{Chl}_{(\mathrm{a}+\mathrm{b})}=\frac{3.5\left(\mathrm{Chl}_{\mathrm{a}}+\mathrm{Chl}_{\mathrm{b}}\right)}{4}
\end{gathered}
$$

where $\mathrm{Chl}_{\mathrm{a}}, \mathrm{Ch}_{\mathrm{b}}$, and $\mathrm{Chl}_{(\mathrm{a}+\mathrm{b})}$ represent chlorophyll $\mathrm{a}_{\mathrm{a}}$, chlorophyll $\mathrm{b}$, and chlorophyll $(\mathrm{a}+\mathrm{b})$, respectively, expressed in $\mathrm{mg} \mathrm{cm}^{-2}$ of fresh leaf area. $\mathrm{A}_{664}$ and $\mathrm{A}_{647}$ denote the absorbance at 664 and $647 \mathrm{~nm}$ wave lengths, respectively. The absorption coefficients are 13.19, 2.57, 22.1 , and 5.26 , while 3.5 is the volume $(\mathrm{mL})$ used in the analysis from the original solution, and 4 is the area of the total disc $\left(\mathrm{cm}^{2}\right)$.

\subsubsection{Physical Attributes of the Fruit}

The fruits were harvested at the $C_{3}$ maturity stage, when two-thirds of the fruit's surface becomes yellow in color [2]. The average weight $(\mathrm{kg})$ of 5 fruits was measured with a digital balance, while the fruit length $(\mathrm{cm})$ and the median width $(\mathrm{cm})$ were measured with a ruler and a rope.

\subsubsection{Quality Attributes of the Fruit}

Total Soluble Solids (TSS)

A digital refractometer (Atago Co. Ltd., Tokyo, Japan) was used to measure the total soluble solid content of the fruit juice [40]. A drop of pulp juice was taken each from the base, mid, and top portions of the fruit and put on the prism of the instrument after calibrating the instrument with distilled water.

\section{Titratable Acidity (TA)}

Titratable acidity was measured according to Lu et al. [41]. About $10 \mathrm{~g}$ of fresh fruit pulp was homogenized with $20 \mathrm{~mL}$ of distilled water and filtered with cotton wool. Approximately 2 drops of $1 \%$ phenolphthalein dye were applied to $5 \mathrm{~mL}$ of the filtrate and titrated to the end of the color with $0.1 \mathrm{~N}$ of sodium hydroxide $(\mathrm{NaOH})$. The volume of the titrate was recorded, and the results were expressed as the percentage citric acid $100 \mathrm{~g}^{-1}$ fresh weight.

\section{Determination of Sugars and Organic Acids}

The extraction was performed according to Lu et al. [42]. Briefly, $5 \mathrm{~g}$ of the sample was homogenized and immersed in $25 \mathrm{~mL}$ of $80 \%(v / v)$ methanol and kept at $30{ }^{\circ} \mathrm{C}$ for $30 \mathrm{~min}$. The supernatant was collected after centrifugation at $10,000 \times \mathrm{g}$ for $5 \mathrm{~min}$, the volume was made $25 \mathrm{~mL}$ with $80 \%$ methanol, and the mixture was placed in a water bath and maintained at $70{ }^{\circ} \mathrm{C}$ until dry. The residual content was then diluted with $10 \mathrm{~mL}$ of deionized water and filtered with a $0.45 \mu \mathrm{m}$ syringe filter before the study. Highperformance liquid chromatography (HPLC) (Agilent, Santa Clara, CA, USA) was used to analyze sugars and organic acids. Analysis of sugars was carried out using a Rezex RPM monosaccharide's $\mathrm{Pb}^{2+}$ column (100 $\mathrm{mm} \times 7.8 \mathrm{~mm}, 8 \mu \mathrm{m}$; Phenomenex, CA, USA) with a

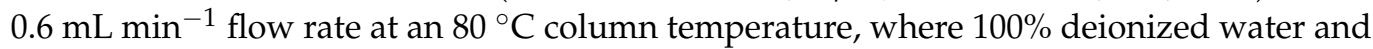
a refractive index detector were used as the mobile phase to detect sugars. Organic acids were analyzed in a Phenomenex organic acid column $(250 \mathrm{~mm} \times 4.6 \mathrm{~mm}, 8 \mu \mathrm{m})$ with a $0.6 \mathrm{~mL} \mathrm{~min}{ }^{-1}$ flow rate, maintaining a $60^{\circ} \mathrm{C}$ column temperature, and a refractive index detector at $40^{\circ} \mathrm{C}$ was used as the mobile phase to detect organic acids. For all analyses, $20 \mu \mathrm{L}$ of the filtrate was used. Sugars and organic acids were detected and calculated with the help of corresponding external standards. 


\section{Nitrogen Use}

Nitrogen use efficiency (NUE) and partial nitrogen factor productivity $\left(\mathrm{PFP}_{\mathrm{N}}\right)$ were measured with the following formula by $\mathrm{Xu}$ et al. [43], as these are potential ways of describing the effectiveness of nitrogen use [44]:

$$
\begin{aligned}
& \text { NUE }=\frac{\text { Yield plant }}{-1}
\end{aligned}
$$

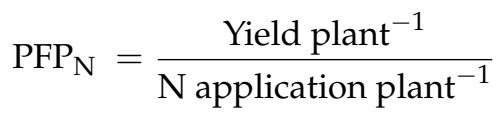

\subsection{Statistical Analysis}

All data were collected from four independent replicates $(n=4)$; for each sample a pool of 3 plants was used and analyzed statistically by one-way analysis of variance (ANOVA) to compare two group mean (urea; Urea with NBPT) using Student's $t$-test $(p \leq 0.05, n=4)$ of $\mathrm{R}$ software. A significant $(p \leq 0.05)$ difference between foliar-applied urea with or without NBPT is shown with asterisks.

\section{Results}

\subsection{Plant Growth and N Accumulation}

All plant growth characteristics of pineapple were positively affected by NLU (urea with NBPT) treatment. All growth parameters, viz. the plant height (Figure 2a), D leaf length (Figure $3 a$ ), D leaf width (Figure $3 b$ ), and the fresh and dry biomass of above-ground (Table 2) and below-ground (Table 3$)$ parts, differed significantly $(p \leq 0.05)$ between both treatments except for the number of leaves (Figure 2b). Figure 2a shows that the plant height increased over time with both treatments and differed significantly $(p \leq 0.05)$ at 8 and $12 \mathrm{MAP}$, but this difference was not significant at 4 MAP. The foliar application of NLU (urea with NBPT) led to taller plants than the treatment with urea alone. The NLU treatment exhibited $2.86 \%, 16 \%$, and $18 \%$ taller plants at 4,8 , and $12 \mathrm{MAP}$, respectively, compared with urea treatment (control).

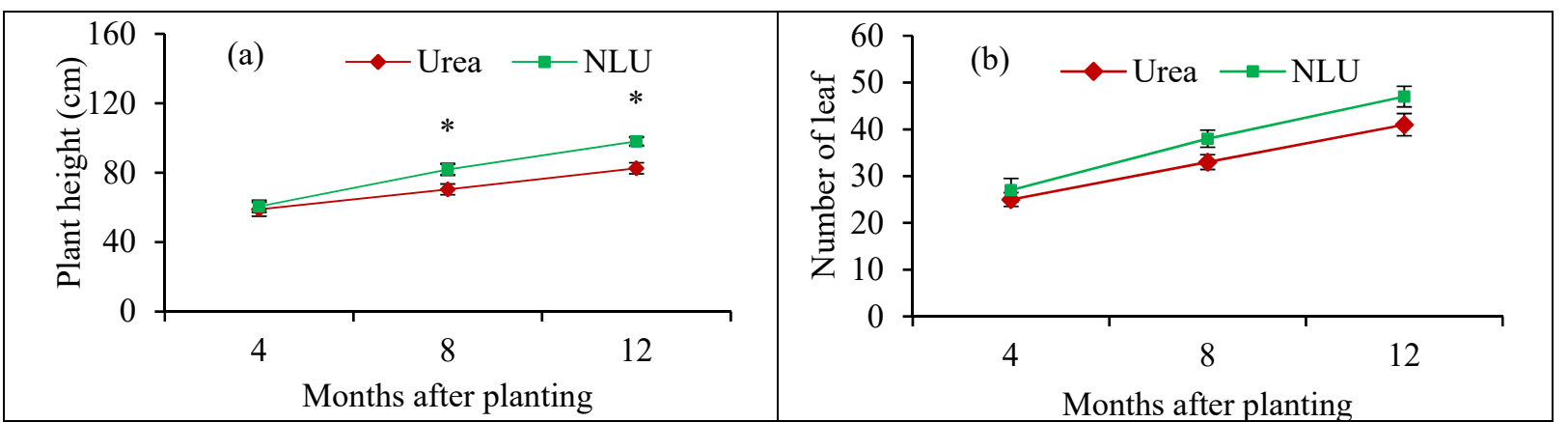

Figure 2. Effect of urea with and without NBPT on (a) plant height and (b) number of leaves at different MAP. Data are reported as the mean \pm standard error $(n=4)$. Asterisks symbolize significant differences $(p \leq 0.05)$ between both treatments. 


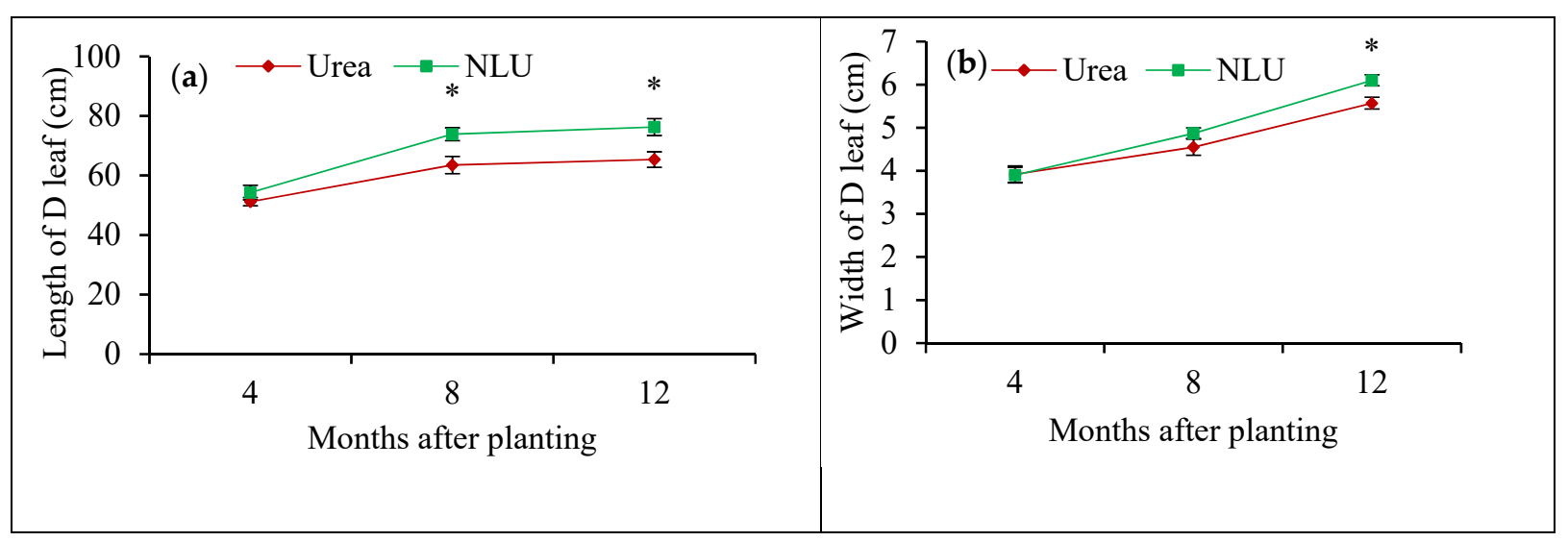

Figure 3. Effect of urea with or without NBPT on (a) D leaf length and (b) D leaf width. Data are reported as the mean \pm standard error $(n=4)$. Asterisks symbolize significant differences $(p \leq 0.05)$ between both treatments.

Table 2. Effects of NBPT on the above-ground biomass of pineapple plants.

\begin{tabular}{ccccccc}
\hline \multirow{2}{*}{ Treatment } & \multicolumn{2}{c}{ Above-Ground Fresh Biomass (kg/plant) } & \multicolumn{3}{c}{ Above-Ground Dry Biomass (g/plant) } \\
\cline { 2 - 7 } & 4 MAP & 8 MAP & 12 MAP & 4 MAP & 8 MAP & 12 MAP \\
\hline Urea & $0.70 \pm 0.049$ & $1.25 \pm 0.043 \mathrm{~b}$ & $2.70 \pm 0.084 \mathrm{~b}$ & $108.47 \pm 3.32 \mathrm{~b}$ & $180.47 \pm 6.63 \mathrm{~b}$ & $378.36 \pm 11.80 \mathrm{~b}$ \\
NLU & $0.75 \pm 0.045$ & $1.50 \pm 0.064 \mathrm{a}$ & $3.12 \pm 0.129 \mathrm{a}$ & $115.39 \pm 4.16 \mathrm{a}$ & $216.68 \pm 8.47 \mathrm{a}$ & $417.81 \pm 9.41 \mathrm{a}$ \\
\hline $\begin{array}{c}\text { Significance } \\
\text { level }\end{array}$ & NS & $*$ & $*$ & NS & $*$ & $*$ \\
\hline
\end{tabular}

${ }^{*}$ indicates a significant difference $(p \leq 0.05)$ and NS indicates a non-significant difference between both treatments according to Student's $t$-test.

Table 3. Effects of NBPT on the below-ground biomass of pineapple plants.

\begin{tabular}{ccccccc}
\hline \multirow{2}{*}{ Treatment } & \multicolumn{2}{c}{ Below-Ground Fresh Biomass (g/Plant) } & \multicolumn{3}{c}{ Below-Ground Dry Biomass (g/Plant) } \\
\cline { 2 - 7 } & $\mathbf{4}$ MAP & $\mathbf{8}$ MAP & 12 MAP & 4 MAP & 8 MAP & 12 MAP \\
\hline Urea & $65.95 \pm 2.51$ & $140.38 \pm 4.99$ & $288.32 \pm 11.91$ & $10.37 \pm 0.39$ & $22.50 \pm 0.93$ & $35.74 \pm 1.78$ \\
NLU & $78.86 \pm 4.95$ & $149.27 \pm 4.58$ & $326.61 \pm 7.65$ & $12.40 \pm 0.77$ & $25.39 \pm 0.88$ & $41.48 \pm 1.14$ \\
\hline $\begin{array}{c}\text { Significance } \\
\text { level }\end{array}$ & NS & NS & $*$ & NS & NS \\
\hline
\end{tabular}

${ }^{*}$ indicates a significant difference $(p \leq 0.05)$ and NS indicates a non-significant difference between both treatments according to Student's $t$-test.

Figure $2 \mathrm{~b}$ depicts the effect of urea and NLU on the number of leaves, which did not differ significantly $(p>0.05)$ between both treatments, but the number was slightly higher with the NLU treatment. The number of leaves ranged from 25 to 41 and from 27 to 47 with the urea and NLU treatments, respectively.

The lengths (Figure $3 a$ ) and widths (Figure $3 b$ ) of the D leaves showed that the D leaf lengths differed significantly ( $p \leq 0.05$ ) at 8 and $12 \mathrm{MAP}$, whereas the widths of the leaves differed only at 12 MAP. There was no significant difference between both treatments in terms of the D leaf length at 4 MAP and the D leaf width at 4 and 8 MAP. The NLU treatment led to longer D leaves compared with the urea treatment alone (control) at all dates of data collection. However, the NLU treatment recorded $6 \%, 16 \%$, and $20 \%$ longer D leaves at 4,8 , and $12 \mathrm{MAP}$, respectively, compared with the urea treatment alone.

The above-ground fresh and dry biomass ( $\mathrm{kg} /$ plant and $\mathrm{g} /$ plant, respectively) between both treatments is presented in Table 3. The pattern of fresh and dry biomass production between both treatments differed significantly at 8 and $12 \mathrm{MAP}$ but remained almost similar at 4 MAP. A higher value of fresh $(0.75,1.50$, and $3.12 \mathrm{~kg} /$ plant $)$ and dry $(115.39,216.68$, and $417.81 \mathrm{~g} /$ plant) biomass production in the above-ground parts was observed after the NLU treatment, while lower fresh $(0.70,1.25$, and $2.70 \mathrm{~kg} / \mathrm{plant})$ and dry $(108.47,180.47$, and $378.36 \mathrm{~g} /$ plant) biomass production was recorded after the urea 
treatment at 4, 8, and $12 \mathrm{MAP}$, respectively. The application of NLU increased the fresh biomass by $20 \%$ and $15 \%$ and the dry biomass by $20 \%$ and $10 \%$ compared with the urea treatment at 8 and $12 \mathrm{MAP}$, respectively.

Moreover, data on the fresh and dry biomass (g/plant) of the below-ground parts revealed that the NLU treatment had a significant positive effect on these traits only at 12 MAP, which was $13 \%$ and $16 \%$ higher, respectively, than that of the urea treatment (Table 3 ).

Chlorophyll is one of the most important factors that influence the photosynthetic capacity of a plant and is significantly affected by NLU. The chlorophyll ${ }_{a}$, chlorophyll ${ }_{b}$, and chlorophyll $(\mathrm{a}+\mathrm{b})$ content at 4, 8, and $12 \mathrm{MAP}$ is presented in Table 4 . The results showed that chlorophyll $a$, chlorophyll $\mathrm{b}_{\mathrm{b}}$, and chlorophyll $(\mathrm{a}+\mathrm{b})$ content increased over time up to the observation period. NLU (urea with NBPT) treatment caused a significant increase in chlorophyll $\mathrm{a}_{\mathrm{a}}$ and total chlorophyll at 8 and $12 \mathrm{MAP}$, but no statistical difference was observed at 4 MAP. However, the chlorophyll $\mathrm{b}_{\mathrm{b}}$ content was comparable between both treatments at any observation time. With the NLU treatment, chlorophyll ${ }_{\mathrm{a}}$ showed higher mean values of 4.45 and $4.90 \mathrm{mg} \mathrm{cm}^{-2}$, and the treatment with urea alone gave lower values of 4.03 and $4.52 \mathrm{mg} \mathrm{cm}^{-2}$ at 8 and $12 \mathrm{MAP}$, respectively. The application of the NBPT with urea increased chlorophyll $(\mathrm{a}+\mathrm{b})$ by $10.76 \%$ and $12.09 \%$ at 8 and $12 \mathrm{MAP}$, respectively, compared with the application of urea alone.

Table 4. Effects of NBPT on the chlorophyll content of pineapple leaves.

\begin{tabular}{|c|c|c|c|c|c|c|c|c|c|}
\hline \multirow{2}{*}{ Treatment } & \multicolumn{3}{|c|}{ Chlorophyll ${ }_{\mathrm{a}}\left(\mathrm{mg} \mathrm{cm}^{-2}\right)$} & \multicolumn{3}{|c|}{ Chlorophyll $_{\mathrm{b}}\left(\mathrm{mg} \mathrm{cm}^{-2}\right)$} & \multicolumn{3}{|c|}{ Chlorophyll $_{(\mathrm{a}+\mathrm{b})}\left(\mathrm{mg} \mathrm{cm}^{-2}\right)$} \\
\hline & 4 MAP & 8 MAP & 12 MAP & 4 MAP & 8 MAP & 12 MAP & 4 MAP & 8 MAP & 12 MAP \\
\hline Urea & $3.49 \pm 0.05$ & $4.03 \pm 0.05$ & $4.52 \pm 0.04$ & $1.02 \pm 0.80$ & $1.15 \pm 0.06$ & $1.52 \pm 0.11$ & $3.94 \pm 0.11$ & $4.55 \pm 0.09$ & $5.21 \pm 0.10$ \\
\hline NLU & $3.47 \pm 0.06$ & $4.45 \pm 0.04$ & $4.90 \pm 0.05$ & $1.05 \pm 0.11$ & $1.32 \pm 0.08$ & $1.78 \pm 0.12$ & $3.95 \pm 0.15$ & $5.04 \pm 0.04$ & $5.84 \pm 0.11$ \\
\hline $\begin{array}{l}\text { Significance } \\
\text { level }\end{array}$ & NS & * & * & NS & NS & NS & NS & * & * \\
\hline
\end{tabular}

* indicates a significant difference $(p \leq 0.05)$ and NS indicates a non-significant difference between both treatments according to Student's $t$-test.

The leaf area per plant is an important parameter of pineapple that indicates the growth of the plant. The data on the leaf area per plant, as influenced by urea with NBPT, are given in Table 5. This parameter was found to increase in different magnitudes with both treatments up to 12 MAP. The rate of increment was higher after the NLU treatment than after the urea treatment. The leaf area per plant was found to differ significantly between both treatments at 8 and 12 MAP. Larger leaf areas were recorded for plants receiving the urea with $\operatorname{NBPT}\left(846.25,2576.89\right.$, and $3475.55 \mathrm{~cm}^{2} /$ plant $)$ compared with plants treated with only urea $\left(730.50,2087.78\right.$, and $3255.11 \mathrm{~cm}^{2} /$ plant $)$ at 4,8 , and $12 \mathrm{MAP}$, respectively. However, the leaf area increased by $8 \%$ at $4 \mathrm{MAP}, 23 \%$ at $8 \mathrm{MAP}$, and $15 \%$ at 12 MAP with the NLU treatment. The foliar application of urea with NBPT had a significant influence on nitrogen accumulation at 12 MAP. The urea with NBPT led to a $10 \%$ increase in $\mathrm{N}$ accumulation per plant compared with urea treatment.

Table 5. Effects of NBPT on leaf area and nitrogen accumulation per pineapple plant.

\begin{tabular}{|c|c|c|c|c|}
\hline \multirow{2}{*}{ Treatment } & \multicolumn{3}{|c|}{ Leaf Area/Plant $\left(\mathrm{cm}^{2}\right)$} & \multirow{2}{*}{$\begin{array}{l}\text { Nitrogen Accumulation } \\
\text { at } 12 \text { MAP (g/Plant) }\end{array}$} \\
\hline & 4 MAP & 8 MAP & 12 MAP & \\
\hline Urea & $780.50 \pm 39.21$ & $2087.78 \pm 77.42$ & $3255.11 \pm 122.55$ & $5.35 \pm 0.20$ \\
\hline NLU & $846.25 \pm 33.79$ & $2576.89 \pm 78.25$ & $3745.55 \pm 147.06$ & $5.90 \pm 0.16$ \\
\hline Significance level & NS & $*$ & $*$ & $*$ \\
\hline
\end{tabular}

* indicates a significant difference $(p \leq 0.05)$ and NS indicates a non-significant difference between both treatments according to Student's $t$-test.

\subsection{Nitrogen Use and Fruit Attributes}

Nitrogen use and the physical and quality attributes of the fruits of MD2 pineapple were affected by foliar application of urea with or without NBPT and are presented in Table 6. Both the $\mathrm{PFP}_{\mathrm{N}}$ and NUE increased with the NLU treatment but in different magnitudes. The $\mathrm{PFP}_{\mathrm{N}}$ of the pineapple increased significantly more (by 13\%) after the NLU treatment than after 
the urea treatment. However, the NUE between both treatments was comparable, while a higher NUE (322.39 $\mathrm{g} \mathrm{g}^{-1}$ ) was recorded after the NLU treatment than after the urea treatment (308.97 $\left.\mathrm{g} \mathrm{g}^{-1}\right)$. Significant variation $(p \leq 0.05)$ was observed in the fruit length and the average fruit weight, but the fruit widths between both treatments were statistically similar. Longer $(18.45 \mathrm{~cm})$ as well as wider $(13.92 \mathrm{~cm})$ fruits were recorded in plants given the NLU treatment, whereas shorter $(15.95 \mathrm{~cm})$ and narrower $(11.46 \mathrm{~cm})$ fruits were obtained from the plants treated with only urea. However, the NLU treatment produced fruits with $15 \%$ more weight than those produced by the treatment with urea alone (control).

Table 6. Effect of NBPT on partial factor productivity, nitrogen use efficiency, fruit yield, and quality attributes of pineapple.

\begin{tabular}{|c|c|c|c|}
\hline \multirow{2}{*}{ Parameters } & \multicolumn{2}{|c|}{ Treatments } & \multirow{2}{*}{ Level of Significance } \\
\hline & Urea & NLU & \\
\hline \multicolumn{4}{|l|}{ Nitrogen Use } \\
\hline $\operatorname{PFP}_{\mathrm{N}}\left(\mathrm{g} \mathrm{g}^{-1}\right)$ & $244.08 \pm 10.53$ & $275.29 \pm 6.27$ & * \\
\hline $\operatorname{NUE}\left(\mathrm{g} \mathrm{g}^{-1}\right)$ & $308.97 \pm 11.76$ & $322.39 \pm 9.66$ & NS \\
\hline \multicolumn{4}{|c|}{ Physical attributes of fruits } \\
\hline Fruit length $(\mathrm{cm})$ & $15.95 \pm 0.55$ & $18.45 \pm 0.53$ & $*$ \\
\hline Fruit width $(\mathrm{cm})$ & $11.46 \pm 0.37$ & $13.92 \pm 0.61$ & NS \\
\hline Average fruit weight $(\mathrm{cm})$ & $1.65 \pm 0.08$ & $1.90 \pm 0.05$ & $*$ \\
\hline \multicolumn{4}{|c|}{ Quality attributes of fruits } \\
\hline Total soluble solids (\% brix) & $13.20 \pm 0.44$ & $15.77 \pm 0.82$ & $*$ \\
\hline Titratable acidity (\% citric acid) & $0.44 \pm 0.02$ & $0.40 \pm 0.01$ & NS \\
\hline Ascorbic acid (mg/100 g FW) & $46.24 \pm 1.20$ & $51.18 \pm 1.49$ & $*$ \\
\hline Juice $\mathrm{pH}$ & $3.78 \pm 0.28$ & $3.90 \pm 0.24$ & NS \\
\hline \multicolumn{4}{|c|}{ Sugars } \\
\hline Sucrose (mg/100 g FW) & $34.12 \pm 1.19$ & $39.05 \pm 1.14$ & $*$ \\
\hline Glucose (mg/100 g FW) & $29.06 \pm 1.04$ & $29.50 \pm 1.18$ & NS \\
\hline Fructose (mg/100 g FW) & $13.45 \pm 0.43$ & $14.84 \pm 0.55$ & NS \\
\hline Total sugar content (mg/100 g FW) & $76.63 \pm 2.50$ & $83.39 \pm 2.69$ & NS \\
\hline \multicolumn{4}{|c|}{ Organic acids } \\
\hline Citric acid (mg g $\left.{ }^{-1} \mathrm{FW}\right)$ & $3.24 \pm 0.25$ & $2.54 \pm 0.15$ & * \\
\hline Malic acid $\left(\mathrm{mg} \mathrm{g}^{-1} \mathrm{FW}\right)$ & $1.01 \pm 0.06$ & $0.86 \pm 0.05$ & * \\
\hline Quinic acid $\left(\mathrm{mg} \mathrm{g}^{-1} \mathrm{FW}\right)$ & $0.91 \pm 0.05$ & $0.84 \pm 0.06$ & NS \\
\hline Total organic acid content $\left(\mathrm{mg} \mathrm{g}^{-1} \mathrm{FW}\right)$ & $5.17 \pm 0.21$ & $4.25 \pm 0.20$ & * \\
\hline
\end{tabular}

* indicates a significant difference $(p \leq 0.05)$ and NS indicates a non-significant difference between both treatments according to Student's $t$-test.

The total soluble solids and the ascorbic acid content were significantly greater $(15.77 \%$ brix and $51.18 \mathrm{mg} 100 \mathrm{~g}^{-1} \mathrm{FW}$, respectively) after the NLU treatment than after the urea

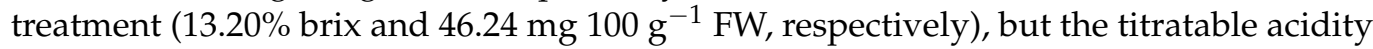
and juice $\mathrm{pH}$ were statistically at par between both treatments. As shown in Table 6, sucrose was found to be the dominant sugar for both treatments, followed by glucose and fructose. The sucrose content differed significantly, whereas the other sugars (glucose and fructose) remained at par between both treatments. A higher $\left(39.05 \mathrm{mg} \mathrm{g}^{-1} \mathrm{FW}\right)$ sucrose content was observed after the NLU treatment than after the urea treatment (control) (34.12 $\left.\mathrm{mg} \mathrm{g}^{-1} \mathrm{FW}\right)$. The second sugar for pineapple was glucose, which ranged from $29.06 \mathrm{mg} \mathrm{g}^{-1} \mathrm{FW}$ after the urea treatment to $29.50 \mathrm{mg} \mathrm{g}^{-1} \mathrm{FW}$ after the NLU treatment. The lower levels of fructose after the urea treatment (control) and the NLU treatment in this study ranged from 13.45 to $14.84 \mathrm{mg} \mathrm{g}^{-1}$ FW. Moreover, after the NLU treatment, all three sugars (sucrose, glucose, and fructose) were $8.82 \%$ higher compared with the urea treatment but did not have a significant influence $(p>0.05)$ between both treatments.

Statistically significant differences in the citric, malic, and total organic acids were detected between both treatments (Table 6). Citric acid was the dominant organic acid; it was higher (3.24 $\left.\mathrm{mg} \mathrm{g}^{-1} \mathrm{FW}\right)$ after the urea treatment than after the NLU treatment (2.54 $\left.\mathrm{mg} \mathrm{g}^{-1} \mathrm{FW}\right)$. Similarly, comparatively higher amounts of malic, quinic, and total organic acids $\left(1.01,0.91\right.$, and $5.17 \mathrm{mg} \mathrm{g}^{-1} \mathrm{FW}$, respectively) were recorded after the urea treatment than after the NLU treatment $\left(0.86,0.84\right.$, and $4.25 \mathrm{mg} \mathrm{g}^{-1} \mathrm{FW}$, respectively). 


\section{Discussion}

\subsection{Plant Growth and N Accumulation}

Nitrogen is the most important nutrient for the growth and development of plants, since it is the main component of chlorophyll and protein [45]. However, rapid urea hydrolysis adversely affects the growth and yield of crops because of high nitrogen losses as ammonia $\left(\mathrm{NH}_{3}\right)$ [16] and nitrate [46]. The use of NBPT with a urea fertilizer for crops is well known [25,47]. Moreover, the application of NBPT with a urea fertilizer significantly increases plant growth in maize [13]. The present findings confirm this claim, as observed in the consistently better results for all growth parameters with the foliar application of urea with NBPT.

The experimental results showed a greater benefit of using NBPT in terms of improving all growth parameters compared with using urea alone. This pattern strongly indicates the possibility of NBPT increasing the studied parameters. The difference between both treatments was statistically at par and small at 4 months after planting in all the parameters, which increased over time, possibly due to the cumulative effect of NBPT. The plant height, leaf number, D leaf length, and D leaf width of the plants were higher after the urea and NBPT treatment than after the urea only treatment. The higher heights of plants receiving the NLU (urea and NBPT) were consistent with the results found for wheat in Brazil [26]. This behavior occurs because NBPT slows down hydrolysis, so the urea remains for a longer time and the plants are able to accumulate more nitrogen (Table 5), which promotes better plant growth through cell division and cell expansion [48]. Dawar et al. [49] supported the substantial increase in pineapple growth due to the application of urea with NBPT. They observed a significantly higher biomass after urea and NBPT treatment than after urea treatment. Galindo et al. [50] reported that increased N uptake and increased chlorophyll after urea and NBPT treatment promote higher photosynthesis, which is the most important mechanism for growth and biomass synthesis in plants, providing a driving force for yield [51]. In this study, NLU treatment led to a significantly higher leaf area compared with urea treatment. This result reveals that NBPT delays the fast hydrolysis of urea, allowing nitrogen to stay for a longer time and be used efficiently, contributing positively to the leaf area through the elongation and expansion of plant leaves [24]. These results corroborated the findings of Zuki et al. [13], who also observed a significantly higher surface leaf area in maize after the NBPT-coated urea treatment than after the urea treatment. A growth analysis also showed that addition of NBPT to urea has a positive impact, particularly on the total plant dry matter, associated with an increase in $\mathrm{N}$ accumulation (Table 5) [52]. Cruchaga et al. [53] observed that tryptophan (an amino acid) content increases in pea plants with the application of urea with NBPT. Tryptophan is a precursor of indole acetic acid (IAA), a phytohormone engaged in physiological activities, such as apical dominance and the generation of plant roots. The increased level of tryptophan in NBPT-treated plants can change the level of auxin, which could help enhance plant growth through increased protein synthesis [54]. On the contrary, a urea-fed plant shows lower growth, which may also be attributed to a higher amount of the nickel-dependent urease enzyme present in plants, as Soni and Korgaokar [55] reported that nickel at higher concentrations adversely affects the biomass yield and growth rate. This finding is also supported by Gad et al. [56], who observed that a higher concentration of nickel has a negative effect on all the growth parameters of tomato. Uruç Parlak [57] also observed a clear growth reduction in wheat with a higher Ni content in the plant, which may interfere with the metabolic activities and biochemical processes, such as protein and chlorophyll synthesis.

Significantly higher chlorophyll $\mathrm{a}_{\mathrm{a}}$ and chlorophyll $_{(\mathrm{a}+\mathrm{b})}$ with the addition of NBPT to urea is due to the positive effect of NBPT on nitrogen uptake as N is a component of chlorophyll [58] and due to a positive correlation between $\mathrm{N}$ and leaf chlorophyll content [59]. Galindo et al. [50] found a significantly higher leaf chlorophyll index with the soil application of urea with NBPT in wheat. Higher nitrogen accumulation through NBPT increases the activation of thylakoid membranes and improves the function of photosystems $[60,61]$. On the contrary, the reduced chlorophyll content in the leaf of a urea- 
fed plant might be explained by the lower amount of nitrogen absorbed by the plant and the inhibition of chlorophyll synthesis by the nickel-containing urease enzyme; as Uruç [57] reported, the chlorophyll content is indirectly proportional to the nickel concentration. According to Dhir et al. [62], this reduction in chlorophyll content might be due to a lower iron content or reduced chlorophyll biosynthesis enzyme activity and the replacement of the central magnesium ion in the chlorophyll by nickel atoms. The NLU treatment showed a higher $\mathrm{N}$ content, which might be due to the inhibitory effect of NBPT, which acts as a urease inhibitor and restricts urea hydrolysis. Similarly, higher nitrogen uptake as a response to NBPT-treated urea was reported by Zuki et al. [13] in maize and by Zaman et al. [63] in grass pasture. In addition, NBPT-treated urea is considered a slow-release fertilizer that maximizes $\mathrm{N}$ uptake in rice [64].

\subsection{Nitrogen Use and Fruit Attribute}

Nitrogen use can be improved by better agronomic approaches, such as fertilizer management and cultivation techniques, which can ensure a higher crop yield and $\mathrm{N}$ efficiency [65]. This study confirmed that high partial factor productivity $\left(\mathrm{PFP}_{\mathrm{N}}\right)$ and nitrogen use efficiency (NUE) can be ensured through the use of NBPT with urea (Table 6). Higher $\mathrm{PFP}_{\mathrm{N}}$ and NUE values were obtained after the NLU treatment, which was comparable with the findings of Zuki et al. [13], who observed that a granular coating of urea with NBPT increases NUE by $51 \%$ to $72 \%$ in maize. The findings of this study are also in line with those of Kawakami et al. [25], who observed that the addition of NBPT increases NUE by $41 \%$ in cotton. Our study demonstrated that the application of urea with NBPT influences the fruit size (length and width) and fruit weight, indicating the positive impact of NBPT on yield-contributing characters. Higher fruit yield after urea and NBPT treatment might be attributed to the longer and broader fruit, as the average fruit weight represents the total yield of a plant because one plant produces one fruit. Our findings are consistent with the findings of Khan et al. [66], who reported an improvement in the yield-contributing character of maize due to the application of NBPT. Moreover, Sossa et al. [2] reported that better growth at flowering time ensures better pineapple fruit quality (fruit length and weight). This study showed better growth after the urea and NBPT treatment, which guaranteed an increased fruit weight and length. NBPT is often used as a fertilizer additive in agriculture to reduce urease activity, slow down urea hydrolysis, and decrease the concentration of ammonia, thereby improving $\mathrm{N}$ use efficiency and increasing crop yield by more than $13 \%$ in wheat [24], $21 \%$ in maize [67], and $22.6 \%$ to $27.82 \%$ in grape [18] at a similar rate as that by urea with or without NBPT. Liu et al. [68] observed that the rice yield significantly increased after urea and NBPT treatment, while other field experiments exhibited no significant yield increase after the use of a urease inhibitor $[29,69,70]$. Two major factors are believed to ensure that the performance of the urease inhibitor does not increase. First, the lower efficiency of the urease inhibitor in decreasing $\mathrm{NH}_{3}$ loss does not sufficiently impact crop yield. Second, if the initial mineral nitrogen levels are high, the conservation of $\mathrm{N}$ by a urease inhibitor can have little effect on yield. In our study, the significant yield increase might have been due to the NBPT, as it is the most efficient urease inhibitor in agriculture so far, and also to the initial lower level of mineral nitrogen in the soil (Table 1). The results of this study are corroborated by previous observations in which the subsequent response to added $\mathrm{N}$ fertilizer has a strong effect on the initial soil nitrate status [71]. Moreover, a meta-analysis by Abalos et al. [72] reported that the application of NBPT may be considered an effective strategy to increase crop yield. Cantarella et al. [12] also observed that NBPT can alter some metabolic pathways and reduces the activity of urease and glutamine synthetase, which are directly related to $\mathrm{N}$ metabolism, which triggers plant growth, thereby increasing the physical attributes of fruits in terms of fruit length, fruit breadth, and average fruit weight.

Some studies have reported that mineral fertilizers affect the quality of fruits [73]. Alva et al. [74] demonstrated that nitrogenous fertilizer application increases yield and enhances the quality of fruits. In fruit trees, $\mathrm{N}$ is a major limiting factor for fruit yield 
as well as quality [75]. In this study, the foliar application of urea with NBPT affected the TSS, titratable acidity, fruit $\mathrm{pH}$, and the ascorbic acid, sugar, and organic acid content. Higher values were globally reported with higher nitrogen doses in pineapple [2] that were related to the urea and NBPT treatment. In this study, juice $\mathrm{pH}$ was found to increase and total titratable acidity was observed to decrease after urea and NBPT treatment, which was analogous to the findings of Agbangba et al. [76], who showed a rise in Smooth Cayenne pineapple $\mathrm{pH}$ due to the nitrogen effect. A reduction in total titratable acidity by a dicyandiamide (DCD) inhibitor in citrus fruits was observed by Serna et al. [77]. The total soluble solids mainly include the total sugar and organic acids, among other constituents. These components are often assessed in the analysis of pineapple as they are responsible for the overall sensory quality of pineapple [42]. In previous research, the total soluble solids increased in pineapple as the nitrogen concentration increased [33]. We also observed a higher total soluble solid content in the fruits of plants treated with urea and NBPT, which permits a more efficient use of nitrogen, unlike urea-fed plants. In pineapple, fruit quality largely depends on the sugar content, which positively correlates with the total soluble solid content [78-80]. Titratable acidity, or the ratio of TSS to TA, is a reliable guide for evaluating pineapple fruit maturity and quality [42], and these values describe the content of organic acids within the fruits. Fruit quality greatly depends on soluble sugars and organic acids, which contribute to the flavor [81], and nitrogen, which has been shown to affect the sugar profile [82]. The highest levels of sucrose, accompanied by glucose and fructose, in pineapple are shown in Table 6, and the results were consistent with previous findings [42]. Selim et al. [30] supported this result, recording superior sugar beet quality in terms of sugar yield and percentage of sucrose after the treatment with urea and a urease inhibitor compared to the treatment with urea and other nitrogen sources. The higher amount of sugar after the NBPT treatment might be due to the activation of sucrose synthetase (SS) and acid invertase (AI), as, according to Liao et al. [83], the activity of these enzymes greatly depends on the nitrogen level. The acidity of pineapple fruit is mainly due to the levels of malic, citric, and quinic acids [42], where nitrogen has the most obvious impact on the citric acid content [84]. The activities of phosphoenolpyruvate carboxylase and citrate synthase are directly related to citric acid synthesis, where aconitase is responsible for citric acid breakdown [85]. Zhou et al. [86] observed that citric acid synthesis resulted from an increased level of citrate synthase and decreased activity of aconitase. In this study, aconitase, which is responsible for a lower amount of citric acid, was probably more active than citrate synthase in NLU-treated plants. The higher levels of citric acid and lower levels of malic acid reported in pineapple were similar to other reports [87,88]. In addition, Cámara et al. [89] observed that pineapple fruit juice contains trace levels of quinic, oxalic, and succinic acids in addition to higher levels of citric and malic acids. Our study also confirmed that a higher amount of ascorbic acid (vitamin C) is obtained from fruits of plants treated with urea and a urease inhibitor. Higher ascorbic acid levels might be attributed to a higher sugar content from this treatment, supported by the positive correlation between ascorbic acid and sugar [90]. Previous studies have reported that higher nitrogen levels increase the ascorbic acid content [91] in citrus fruits; conversely, Omotoso and Akinrinde [32] observed that an increase in N supply decreases the ascorbic acid content in pineapple. Generally, nitrogen fertilizer, especially in higher amounts, seems to lower vitamin C levels in some fruits and vegetables, but the response may vary with the plant variety and genus, weather, and other factors [83,92]. Moreover, Miceli and Miceli [93] concluded that nitrogen at a suboptimal level tends to decrease the vitamin $C$ content, indicating that sufficient nitrogen is required to maintain ascorbic acid synthesis. Our study revealed that the overall superior quality of pineapple fruits from plants treated with urea and NBPT might be due to the function of NBPT in delaying the fast hydrolysis of urea, lowering $\mathrm{NH}_{3}$ emission and increasing the availability of nitrogen to the plant. 


\section{Conclusions}

In summary, the application of urea with NBPT improved most of the studied growth parameters, including the chlorophyll content of pineapple. The physical attributes (except fruit width) and the quality attributes (except titratable acidity and $\mathrm{pH}$ ) of the fruit were found to improve with the application of NLU (urea with NBPT). Compared to a plain urea fertilizer, NBPT-amended urea greatly enhanced the partial factor productivity and the nitrogen use efficiency. This supports the hypothesis that $\mathrm{N}$ loss from plain urea can be effectively reduced by urease inhibitors, concomitantly improving the growth, yield, and fruit quality attributes of pineapple. However, this study was not able to affirm the significant effect of NBPT on pineapple growth, yield, and quality under open-field conditions; hence, field work is needed to verify this result in real situations. Moreover, no negative impact of NBPT addition to foliar urea was observed. Thus, the use of NBPT with urea could be beneficial for pineapple growth, yield, and quality.

Author Contributions: M.A.H. implemented all the research work. S.Z.S., P.D., N.M.J., and B.C.S. supervised the research work. S.Z.S. and N.M.J. gave advice during the planning and execution of the research and provided technical support. M.K.Y. was also engaged in supervision and selection of methodology. This manuscript was written by M.A.H. with assistance from S.Z.S. and B.C.S. All authors have read and agreed to the published version of the manuscript.

Funding: This research work was conducted with the financial support of the Project Implementation Unit, National Agricultural Technology Programme, Bangladesh Agricultural Research Council, Ministry of Agriculture, People's Republic of Bangladesh.

Institutional Review Board Statement: Not applicable.

Informed Consent Statement: Not applicable.

Data Availability Statement: Not applicable.

Acknowledgments: Mohammad Amdadul Haque would like to express his gratitude to the authority of the National Agricultural Technology Programme, the Bangladesh Agricultural Research Council, and the Bangladesh Agricultural Research Institute for providing the fellowship to perform research at the Faculty of Agriculture, Universiti Putra Malaysia. All faculty members and staff of the crop science department are acknowledged for their continuous technical support and cooperation in helping complete the research. The authors are thankful to $\mathrm{KOCH}$ industries, Inc. for providing NBPT to implement this research.

Conflicts of Interest: The authors have declared that there is no conflict of interest.

\section{References}

1. Reinhardt, D.H.R.C.; Bartholomew, D.P.; Souza, F.V.D.; de Carvalho, A.C.P.P.; de Pádua, T.R.P.; Junghans, D.T.; de Matos, A.P. Advances in pineapple plant propagation. Rev. Bras. Frutic. 2018, 40,1-22. [CrossRef]

2. Sossa, E.L.; Agbangba, C.E.; Accalogoun, S.G.G.S.; Amadji, G.L.; Agbossou, K.E.; Hounhouigan, D.J. Residues management practices and nitrogen-potassium fertilization influence on the quality of pineapple (Ananas comosus L. Merrill) sugarloaf fruit for exportation and local consumption. Agronomy 2017, 7, 26. [CrossRef]

3. FAOSTAT. Crop Statistics, Food and Agriculture Organization of the United Nations; FAO: Rome, Italy, 2020.

4. Herrera, J.M.; Rubio, G.; Häner, L.L.; Delgado, J.A.; Lucho-Constantino, C.A.; Islas-Valdez, S.; Pellet, D. Emerging and established technologies to increase nitrogen use efficiency of cereals. Agronomy 2016, 6, 25. [CrossRef]

5. Chen, K.E.; Chen, H.Y.; Tseng, C.S.; Tsay, Y.F. Improving nitrogen use efficiency by manipulating nitrate remobilization in plants. Nat. Plants 2020, 2. [CrossRef] [PubMed]

6. Van Ut, L.; Mai, V.T.B. Effect of gibberellic acid and urea on the growth of pineapple fruit (Ananas comosus L.) Merr. Sci. Technol. Dev. J. Nat. Sci. 2019, 3. [CrossRef]

7. Hristov, A.N.; Bannink, A.; Crompton, L.A.; Huhtanen, P.; Kreuzer, M.; McGee, M.; Nozière, P.; Reynolds, C.K.; Bayat, A.R.; Yáñez-Ruiz, D.R.; et al. Invited review: Nitrogen in ruminant nutrition: A review of measurement techniques. J. Dairy Sci. 2019, 102, 5811-5852. [CrossRef] [PubMed]

8. Mcallister, C.H.; Beatty, P.H.; Good, A.G. Engineering nitrogen use efficient crop plants: The current status. Plant Biotechnol. J. 2012, 10, 1011-1025. [CrossRef] [PubMed] 
9. Hefley, C.; Rhoades, M.; Blaser, B.; Parker, D. Nutrient content of wheat and corn in response to the application of urea and the urease inhibitor NPBT. In Proceedings of the 2017 ASABE Annual International Meeting, Spokane, DC, USA, 16-19 July 2017; American Society of Agricultural and Biological Engineers: St. Joseph, Michigan, 2017; p. 1.

10. Zörb, C.; Ludewig, U.; Hawkesford, M.J. Perspective on wheat yield and quality with reduced nitrogen supply. Trends Plant Sci. 2018, 23, 1029-1037. [CrossRef]

11. Grant, C.A.; Moulin, A.P.; Tremblay, N. Nitrogen management effects on spring wheat yield and protein concentration vary with seeding date and slope position. Agron. J. 2016, 108, 1246-1256. [CrossRef]

12. Cantarella, H.; Otto, R.; Soares, J.R.; de Brito Silva, A.G. Agronomic efficiency of NBPT as a urease inhibitor: A review. J. Adv. Res. 2018, 13, 19-27. [CrossRef]

13. Zuki, M.M.M.; Jaafar, N.M.; Sakimin, S.Z.; Yusop, M.K. N-(n-Butyl) thiophosphoric triamide (NBPT)-coated urea (NCU) improved maize growth and nitrogen use efficiency (NUE) in highly weathered tropical soil. Sustainability 2020, 12, 8780. [CrossRef]

14. Rawluk, C.D.L.; Grant, C.A.; Racz, G.J. Ammonia volatilization from soils fertilized with urea and varying rates of urease inhibitor NBPT. Can. J. Soil Sci. 2001, 81, 239-246. [CrossRef]

15. Chien, S.H.; Prochnow, L.I.; Cantarella, H. Recent Developments of Fertilizer Production and Use to Improve Nutrient Efficiency and Minimize Environmental Impacts, 1st ed.; Elsevier Inc.: Amsterdam, The Netherlands, 2009; Volume 102, ISBN 9780123748188.

16. Silva, D.R.G.; Pereira, A.F.; Dourado, R.L.; Silva, F.P.D.; Ávila, F.W.; Faquin, V. Productivity and efficiency of nitrogen fertilization in maize under different levels of urea and NBPT-treated urea. Ciência Agrotecnologia 2011, 35, 516-523. [CrossRef]

17. Dawar, K.; Zaman, M.; Rowarth, J.S.; Blennerhassett, J.; Turnbull, M.H. The impact of urease inhibitor on the bioavailability of nitrogen in urea and in comparison with other nitrogen sources in ryegrass (Lolium perenne L.). Crop Pasture Sci. 2010, 61, 214-221. [CrossRef]

18. Chuan, L.; Zhao, T.; An, Z.; Du, L.; Li, S. Effects of a urease inhibitor NBPT on the growth and quality of rape. In Proceedings of the 19th World Congress of Soil Science: Soil Solutions for a Changing World, Brisbane, Australia, 1-6 August 2010; pp. 50-52.

19. Silva, A.G.B.; Sequeira, C.H.; Sermarini, R.A.; Otto, R. Urease inhibitor NBPT on ammonia volatilization and crop productivity: A meta-analysis. Agron. J. 2017, 109, 1-13. [CrossRef]

20. Blennerhassett, J.D.; Quin, B.F.; Zaman, M.; Ramakrishnan, C. The potential for increasing nitrogen responses using Agrotain treated urea. In Proceedings of the New Zealand Grassland Association, Wellington, New Zealand, 10 June 2006 ; pp. $297-301$.

21. Martin, R.J.; van der Weerden, T.J.; Riddle, M.U.; Butler, R.C. Comparison of Agrotain-treated and standard urea on an irrigated dairy pasture. In Proceedings of the New Zealand Grassland Association, Wellington, New Zealand, 1 January 2008 ; pp. 91-94.

22. Zaman, M.; Nguyen, M.L.; Blennerhassett, J.D.; Quin, B.F. Reducing $\mathrm{NH}_{3}, \mathrm{~N}_{2} \mathrm{O}$ and $\mathrm{NO}_{3}{ }^{-}-\mathrm{N}$ losses from a pasture soil with urease or nitrification inhibitors and elemental S-amended nitrogenous fertilizers. Biol. Fertil. Soils 2008, 44, 693-705. [CrossRef]

23. Mathialagan, R.; Mansor, N.; Shamsuddin, M.R. Kinetic properties of soil urease inhibited by allicin and NBPT (N-(n-butyl) thiophosphoric triamide). AIP Conf. Proc. 2019, 2124. [CrossRef]

24. Curitiba Espindula, M.; Soares Rocha, V.; Alves de Souza, M.; Campanharo, M.; de Sousa Paula, G. Rates of urea with or without urease inhibitor for topdressing wheat. Chil. J. Agric. Res. 2013, 73, 160-167. [CrossRef]

25. Kawakami, E.M.; Oosterhuis, D.M.; Snider, J.L.; Mozaffari, M. Physiological and yield responses of field-grown cotton to application of urea with the urease inhibitor NBPT and the nitrification inhibitor DCD. Eur. J. Agron. 2012, 43, 147-154. [CrossRef]

26. Espindula, M.C.; Rocha, V.S.; de Souza, M.A.; Campanharo, M.; Badaró Pimentel, A.J. Urease inhibitor (NBPT) and efficiency of single or split application of urea in wheat crop. Rev. Ceres. 2014, 61, 273-279. [CrossRef]

27. Khan, M.A.; Shah, Z.; Rab, A.; Arif, M.; Shah, T. Effect of urease and nitrification inhibitors on wheat yield. Sarhad J. Agric. 2013, $29,371-378$.

28. Rekowski, A.; Wimmer, M.A.; Hitzmann, B.; Hermannseder, B.; Hahn, H.; Zörb, C. Application of urease inhibitor improves protein composition and bread-baking quality of urea fertilized winter wheat. J. Plant Nutr. Soil Sci. 2020, 183, 260-270. [CrossRef]

29. Li, Q.; Yang, A.; Wang, Z.; Roelcke, M.; Chen, X.; Zhang, F.; Pasda, G.; Zerulla, W.; Wissemeier, A.H.; Liu, X. Effect of a new urease inhibitor on ammonia volatilization and nitrogen utilization in wheat in north and northwest China. Field Crop. Res. 2015, 175, 96-105. [CrossRef]

30. Selim, E.M.; Elsirafy, Z.M.; Taha, A.A. Effect of irrigation methods and N-applications on the utilization of nitrogen by sugar beet grown under arid condition. Aust. J. Basic Appl. Sci. 2010, 4, 2114-2124.

31. Sakimin, S.Z.; Samah, M.N.G.A.; Juraimi, A.S.; Alam, M.A.; Aslani, F. Effects of different type of fertilizers on growth and physiology of MD2 pineapple. Bangladesh J. Bot. 2017, 46, 489-495.

32. Omotoso, S.O.; Akinrinde, E.A. Effect of nitrogen fertilizer on some growth, yield and fruit quality parameters in pineapple (Ananas comosus) plant at Ado-Ekiti Southwestern, Nigeria. Int. Res. J. Agric. Sci. Soil Sci. 2013, 3, 11-16.

33. Tewodros, M.; Mesfin, S.; Getachew, W.; Ashenafi, A.; Neim, S. Effect of Inorganic N and P Fertilizers on Fruit Yield and Yield Components of Pineapple (Annanas comosus MERR L. Var. Smooth cayanne) at Jimma, Southwest Ethiopia. Agrotechnology 2018, 07, 1-6. [CrossRef]

34. Bremner, J.M. Total Nitrogen. In Methods of Soil Analysis; Soil Science Society of America and American Society of Agronomy: Madison, WI, USA, 1996; pp. 1085-1121.

35. Bray, R.H.; Kurtz, L.T. Determination of total, organic, and available forms of phosphorus in soils. Soil Sci. 1945, 59, 39-46. [CrossRef]

36. Chapman, H.D. Cation exchange capacity. Agron. J. 1965, 9, 891-901. 
37. Keeney, D.R.; Nelson, D.W. Nitrogen-Inorganic forms. In Methods of Soil Analysis: Part 2 Chemical and Microbiological Properties; Wiley Online Library: Hoboken, NJ, USA, 1983; Volume 9, pp. 643-698.

38. Dos Santos, M.P.; Maia, V.M.; Oliveira, F.S.; Pegoraro, R.F.; Dos Santos, S.R.; Aspiazú, I. Estimation of total leaf area and d leaf area of pineapple from biometric characteristics. Rev. Bras. Frutic. 2018, 40, 4-7. [CrossRef]

39. Aiman, M.; Sakimin, S.Z.; Juraimi, A.S.; Ramlan, F.; Jaafar, H.Z.E.; Ali, B.; Siti, N. Effect of different water regimes and plant growth regulators on growth, physiology and yield of banana (Musa acuminata cv. Berangan) in tropical climate. Fundam. Appl. Agric. 2018, 3, 505-514.

40. Fernandes, A.G.; Santos, G.M.d.; Silva, D.S.d.; Sousa, P.H.M.d.; Maia, G.A.; Figueiredo, R.W. de Chemical and physicochemical characteristics changes during passion fruit juice processing. Ciência Tecnol. Aliment. 2011, 31, 747-751. [CrossRef]

41. Lu, X.H.; Sun, D.Q.; Mo, Y.W.; Xi, J.G.; Sun, G.M. Effects of post-harvest salicylic acid treatment on fruit quality and anti-oxidant metabolism in pineapple during cold storage. J. Hortic. Sci. Biotechnol. 2010, 85, 454-458. [CrossRef]

42. Lu, X.H.; Sun, D.Q.; Wu, Q.S.; Liu, S.H.; Sun, G.M. Physico-chemical properties, antioxidant activity and mineral contents of pineapple genotypes grown in China. Molecules 2014, 19, 8518-8532. [CrossRef] [PubMed]

43. Xu, C.; Huang, S.; Tian, B.; Ren, J.; Meng, Q.; Wang, P. Manipulating planting density and nitrogen fertilizer application to improve yield and reduce environmental impact in Chinese Maize production. Front. Plant Sci. 2017, 8, 1-11. [CrossRef] [PubMed]

44. Ferguson, R.B. Groundwater Quality and Nitrogen Use Efficiency in Nebraska's Central Platte River Valley. J. Environ. Qual. 2015, 44, 449-459. [CrossRef] [PubMed]

45. Leghari, S.J.; Wahocho, N.A.; Laghari, G.M.; HafeezLaghari, A.; MustafaBhabhan, G.; HussainTalpur, K.; Bhutto, T.A.; Wahocho, S.A.; Lashari, A.A. Role of nitrogen for plant growth and development: A review. Adv. Environ. Biol. 2016, 10, $209-219$.

46. Wang, Z.H.; Li, S.X. Nitrate N Loss by Leaching and Surface Runoff in Agricultural Land: A Global Issue (A Review), 1st ed.; Elsevier Inc.: Amsterdam, The Netherlands, 2019; Volume 156, ISBN 9780128175989.

47. Mozaffari, M.; Slaton, N.A.; Long, J.; Kelley, J.; Chlapecka, R.; Wimberley, R. Effect of urea and urea treated with Agrotain on corn grain yield in Arkansas. In AAES Research Series 558: W.E. Sabbe Arkansas Soil Fertility Studies; University of Arkansas System: Fayetteville, NC, USA, April 2008; pp. 38-40.

48. Luo, L.; Pan, S.; Liu, X.; Wang, H.; Xu, G. Nitrogen deficiency inhibits cell division-determined elongation, but not initiation, of rice tiller buds. Isr. J. Plant Sci. 2017, 64, 32-40. [CrossRef]

49. Dawar, K.; Zaman, M.; Rowarth, J.S.; Blennerhassett, J.; Turnbull, M.H. Urease inhibitor reduces N losses and improves plantbioavailability of urea applied in fine particle and granular forms under field conditions. Agric. Ecosyst. Environ. 2011, 144, 41-50. [CrossRef]

50. Galindo, F.S.; Filho, M.C.M.T.; Buzetti, S.; Pagliari, P.H.; Santini, J.M.K. Can NBPT urease inhibitor in combination with Azospirillum brasilense inoculation improve wheat development? Nutr. Cycl. Agroecosystems 2020, 117, 131-143. [CrossRef]

51. Khan, A.; Najeeb, U.; Wang, L.; Tan, D.K.Y.; Yang, G.; Munsif, F.; Ali, S.; Hafeez, A. Planting density and sowing date strongly influence growth and lint yield of cotton crops. Field Crop. Res. 2017, 209, 129-135. [CrossRef]

52. Chen, Z.; Tao, X.; Khan, A.; Tan, D.K.Y.; Luo, H. Biomass accumulation, photosynthetic traits and root development of cotton as affected by irrigation and nitrogen-fertilization. Front. Plant Sci. 2018, 9, 1-14. [CrossRef] [PubMed]

53. Cruchaga, S.; Artola, E.; Lasa, B.; Ariz, I.; Irigoyen, I.; Moran, J.F.; Aparicio-Tejo, P.M. Short term physiological implications of NBPT application on the N metabolism of Pisum sativum and Spinacea oleracea. J. Plant Physiol. 2011, 168, 329-336. [CrossRef]

54. Erland, L.A.E.; Saxena, P. Auxin driven indoleamine biosynthesis and the role of tryptophan as an inductive signal in Hypericum perforatum (L.). PLoS ONE 2019, 14, 1-22. [CrossRef]

55. Soni, K.V.; Korgaokar, S.S. Effect of nickel and zinc metal on biomass and growth rate of some pulses. Int. J. Adv. Res. 2016, 4, 1678-1689. [CrossRef]

56. Gad, N.; El-Sherif, M.H.; El-Gereedly, N.H.M. Influence of Nickel on Some Physiological Aspects of Tomato Plants. Aust. J. Basic Appl. Sci. 2007, 1, 286-293.

57. Uruç Parlak, K. Effect of nickel on growth and biochemical characteristics of wheat (Triticum aestivum L.) seedlings. NJAS Wageningen J. Life Sci. 2016, 76, 1-5. [CrossRef]

58. Bassi, D.; Menossi, M.; Mattiello, L. Nitrogen supply influences photosynthesis establishment along the sugarcane leaf. Sci. Rep. 2018, 8, 1-13. [CrossRef]

59. Buscaglia, H.J.; Varco, J.J. Early detection of cotton leaf nitrogen status using leaf reflectance. J. Plant Nutr. 2002, 25, 2067. [CrossRef]

60. Flexas, J.; Bota, J.; Galmes, J.; Medrano, H.; Ribas-Carbó, M. Keeping a positive carbon balance under adverse conditions: Responses of photosynthesis and respiration to water stress. Physiol. Plant. 2006, 127, 343-352. [CrossRef]

61. Ladjal, M.; Epron, D.; Ducrey, M. Effects of drought preconditioning on thermotolerance of photosystem II and susceptibility of photosynthesis to heat stress in cedar seedlings. Tree Physiol. 2000, 20, 1235-1241. [CrossRef]

62. Dhir, B.; Sharmila, P.; Pardha Saradhi, P.; Nasim, S.A. Physiological and antioxidant responses of Salvinia natans exposed to chromium-rich wastewater. Ecotoxicol. Environ. Saf. 2009, 72, 1790-1797. [CrossRef]

63. Zaman, M.; Zaman, S.; Adhinarayanan, C.; Nguyen, M.L.; Nawaz, S.; Dawar, K.M. Effects of urease and nitrification inhibitors on the efficient use of urea for pastoral systems. Soil Sci. Plant Nutr. 2013, 59, 649-659. [CrossRef] 
64. Khan, A.Z.; Ali, B.; Afzal, M.; Wahab, S.; Khalil, S.K.; Amin, N.; Ping, Q.; Qiaojing, T.; Zhou, W. Effects of sulfur and urease coated controlled release urea on dry matter yield, $\mathrm{n}$ uptake and grain quality of rice. J. Anim. Plant Sci. 2015, 25, 679-685.

65. Cui, Z.; Zhang, F.; Mi, G.; Chen, F.; Li, F.; Chen, X.; Li, J.; Shi, L. Interaction between genotypic difference and nitrogen management strategy in determining nitrogen use efficiency of summer maize. Plant Soil 2009, 317, 267-276. [CrossRef]

66. Khan, M.J.; Malik, A.; Zaman, M.; Khan, Q. Nitrogen use efficiency and yield of maize crop as affected by agrotain coated urea in arid calcareous soils. Soil Environ. 2014, 33.

67. Venterea, R.T.; Maharjan, B.; Dolan, M.S. Fertilizer source and tillage effects on yield-scaled nitrous oxide emissions in a corn cropping system. J. Environ. Qual. 2011, 40, 1521-1531. [CrossRef]

68. Liu, K.; Li, Y.; Hu, H. Estimating the effect of urease inhibitor on rice yield based on NDVI at key growth stages. Front. Agric. Sci. Eng. 2014, 1, 150-157. [CrossRef]

69. Henning, S.W.; Branham, B.E.; Mulvaney, R.L. Response of turfgrass to urea-based fertilizers formulated to reduce ammonia volatilization and nitrate conversion. Biol. Fertil. Soils 2013, 49, 51-60. [CrossRef]

70. Suter, H.; Sultana, H.; Turner, D.; Davies, R.; Walker, C.; Chen, D. Influence of urea fertiliser formulation, urease inhibitor and season on ammonia loss from ryegrass. Nutr. Cycl. Agroecosystems 2013, 95, 175-185. [CrossRef]

71. Cui, Z.; Chen, X.; Miao, Y.; Li, F.; Zhang, F.; Li, J.; Ye, Y.; Yang, Z.; Zhang, Q.; Liu, C. On-farm evaluation of winter wheat yield response to residual soil nitrate-N in North China Plain. Agron. J. 2008, 100, 1527-1534. [CrossRef]

72. Abalos, D.; Jeffery, S.; Sanz-Cobena, A.; Guardia, G.; Vallejo, A. Meta-analysis of the effect of urease and nitrification inhibitors on crop productivity and nitrogen use efficiency. Agric. Ecosyst. Environ. 2014, 189, 136-144. [CrossRef]

73. Darnaudery, M.; Fournier, P.; Léchaudel, M. Low-Input pineapple crops with high quality fruit: Promising impacts of locally integrated and organic fertilization compared to chemical fertilizers. Exp. Agric. 2018, 54, 286-302. [CrossRef]

74. Alva, A.K.; Mattos Jr, D.; Quaggio, J.A. Advances in nitrogen fertigation of citrus. J. Crop Improv. 2008, 22, 121-146. [CrossRef]

75. Wenqing, L.; Min, Z.; Huairui, S. The physiological effects of nitrogen on fruit trees. Shandong Nongye Daxue Xuebao 2002, $33,96-100$.

76. Agbangba, C.E.; Dagbenonbakin, G.D.; Djogbenou, C.P.; Houssou, P.; Assea, E.D.; Sossa, E.L.; Kotomale, U.A.; Ahotonou, P.; Ndiaga, C.; Akpo, L.E. Influence de la fertilisation minérale sur la qualité physico-chimique et organoleptique du jus d'ananas transformé de Cayenne lisse au Bénin. Int. J. Biol. Chem. Sci. 2015, 9, 1277-1288. [CrossRef]

77. Serna, M.D.; Legaz, F.; Primo-Millo, E. Improvement of the N fertilizer efficiency with dicyandiamide (DCD) in citrus trees. In Fertilizers and Environment; Springer: Berlin/Heidelberg, Germany, 1996; pp. 205-210.

78. Pistón, F.; Pérez, A.G.; Sanz, C.; Refoyo, A. Relationship between sugar content and brix as influenced by cultivar and ripening stages of strawberry. Acta Hortic. 2017, 1156, 491-495. [CrossRef]

79. Hajar, N.; Zainal, S.; Nadzirah, K.Z.; Roha, A.M.S.; Atikah, O.; Elida, T.Z.M.T. Physicochemical Properties Analysis of Three Indexes Pineapple (Ananas Comosus) Peel Extract Variety N36. APCBEE Procedia 2012, 4, 115-121. [CrossRef]

80. Chuenboonngarm, N.; Juntawong, N.; Engkagul, A.; Arirob, W.; Peyachoknakul, S. Changing in TSS, TA and sugar contents and sucrose synthase activity in ethephon-treated 'Pattavia' pineapple fruit. Agric. Nat. Resour. 2007, 41, $205-212$.

81. Zhang, Y.; Hu, C.X.; Tan, Q.L.; Zheng, C.S.; Gui, H.P.; Zeng, W.N.; Sun, X.C.; Zhao, X.H. Plant nutrition status, yield and quality of satsuma mandarin (Citrus unshiu Marc.) under soil application of Fe-EDDHA and combination with zinc and manganese in calcareous soil. Sci. Hortic. 2014, 174, 46-53. [CrossRef]

82. Schaller, R.G.; Schnitzler, W.H. Nitrogen nutrition and flavour compounds of carrots (Daucus carota L) cultivated in Mitscherlich pots. J. Sci. Food Agric. 2000, 80, 49-56. [CrossRef]

83. Liao, L.; Dong, T.; Qiu, X.; Rong, Y.; Wang, Z.; Zhu, J. Nitrogen nutrition is a key modulator of the sugar and organic acid content in citrus fruit. PLoS ONE 2019, 14, e223356. [CrossRef]

84. Jakopic, J.; Veberic, R.; Zupancic, K.; Štampar, F. Influence of nitrogen on the contents of carbohydrates and organic acids in apples (Malus domestica Borkh.) cv. "Golden Delicious.". Eur. J. Hortic. Sci. 2007, 72, 66-72.

85. Jiang, N.; Jin, L.F.; Teixeira da Silva, J.A.; Islam, M.Z.; Gao, H.W.; Liu, Y.Z.; Peng, S.A. Activities of enzymes directly related with sucrose and citric acid metabolism in citrus fruit in response to soil plastic film mulch. Sci. Hortic. 2014, 168, 73-80. [CrossRef]

86. Zhou, Y.; He, W.; Zheng, W.; Tan, Q.; Xie, Z.; Zheng, C.; Hu, C. Fruit sugar and organic acid were significantly related to fruit Mg of six citrus cultivars. Food Chem. 2018, 259, 278-285. [CrossRef]

87. Chan, H.T.; Chenchin, E.; Vonnahme, P. Nonvolatile Acids in Pineapple Juice. J. Agric. Food Chem. 1973, 21, 208-211. [CrossRef]

88. Saradhuldhat, P.; Paull, R.E. Pineapple organic acid metabolism and accumulation during fruit development. Sci. Hortic. 2007, 112, 297-303. [CrossRef]

89. Cámara, M.M.; Díez, C.; Torija, M.E.; Cano, M.P. HPLC determination of organic acids in pineapple juices and nectars. Z. Lebensm. Unters. Forsch. 1994, 198, 52-56. [CrossRef]

90. Magwaza, L.S.; Opara, U.L.; Cronje, P.J.R.; Landahl, S.; Terry, L.A. Canopy position affects rind biochemical profile of “Nules Clementine" mandarin fruit during postharvest storage. Postharvest Biol. Technol. 2013, 86, 300-308. [CrossRef]

91. Wassel, A.H.; Ahmed, F.F.; Ragab, M.A.; Ragab, M.M. Response of balady mandarin trees to drip irrigation and nitrogen fertigation, I-Effect of nitrogen fertigation and drip irrigation on the vegetative growth and the yield of balady mandarin trees (Citrus reticulata). In Proceedings of the 8th African Crop Science Society Conference, El-Minia, Egypt, 27-31 October 2007; African Crop Science Society: El-Minia, Egypt; pp. 503-511. 
92. Stefanelli, D.; Goodwin, I.; Jones, R. Minimal nitrogen and water use in horticulture: Effects on quality and content of selected nutrients. Food Res. Int. 2010, 43, 1833-1843. [CrossRef]

93. Miceli, A.; Miceli, C. Effect of nitrogen fertilization on the quality of swiss chard at harvest and during storage as minimally processed produce. J. Food Qual. 2014, 37, 125-134. [CrossRef] 